\title{
Rhythmic Gymnastics Development to Increase Rough Motor Skills in Elementary School Student
}

\author{
Jeane Betty Kurnia Jusuf ${ }^{*}$, K Khatimah ${ }^{1}$, Y Rahmawati ${ }^{1}$, Julianur ${ }^{1}$, N A Mahardhika ${ }^{1}$, \\ Januar Abdilah Santoso ${ }^{1}$ \\ ${ }^{1}$ Faculty of Teacher Training and Education, Universitas Muhammadiyah Kalimantan Timur, Samarinda, Indonesia
${ }^{*}$ Corresponding author. Email: Jbk567@ umkt.ac.id
}

\begin{abstract}
The purpose of this research was to identify the rough motor skills of students before and after the rhythmic gymnastics' activities, and the application of it to improve rough motor of the students. The sample was from the upper class of Islamic Centre Elementary school which where the students' rough motor skills were not optimal based on the preliminary observation. The method was Classroom action research (CAR) which consisted of two cycles. Classroom Action Research methods included: Planning, acting, and reflecting. The data collection techniques were used observations and documentations. The subjects were 25 students consisting of 15 boys and 10 girls. The data collections of instruments were in the form of checklist observation and pictures document as well as videos. The data analysis technique used is qualitative and quantitative analysis. The result of the research showed that the rough motor skills of the students during prior observation is $26 \%$ with medium criteria, in the first cycle increased to $53.4 \%$ with high criteria, and in Cycle II to $81 \%$ with very high criteria. It concluded that rhythmic gymnastics through traditional song can increase rough motor skills in elementary school students.
\end{abstract}

Keywords: rhythmic gymnastics, rough motor skills, elementary school

\section{INTRODUCTION}

One of the children developments who can be stimulated is motor development. Motor development can be defined as the strengthening and physical growth from muscles, child's bones, and capability to touch and move everything around them. Motor development is a change in the ability of movement from infancy to adulthood that requires various aspects protection of abilities [1]. Movement can be treated and supported by using tool or equipment for example previous researcher revealed that stick gymnastic as a knowledge media for elementary school students, making students actively doing movement, and can be received by students and physical education teachers [2]. In fact, several movements don't support any equipment. However, it can be collaborated by another media to make it more attractive. Movements are not merely served insight into the knowledge possessed by a speaker, otherwise, it provides insight into how that knowledge is represented [3].

Generally, gestures are included of the human movement. Gestures familiarly can be identified as the communication of information which understood motoric or spatially but that has not yet been verbally or linguistically encoded while in specific age, children are supported to be flexible in movement. The ages mentioned are when they are in elementary school ages.
Generally, Age is a short period of child development nonetheless it is very important period for their life [4]. Moreover, Dayu gymnastics product (Dayak Gymnastics and Melayu dance) as an alternative learning rhythmic activity for physical education in school's environment [5]. Another consequence was come from gross motor development of children is an effort to enhance the mastery of skills portrayed in the ability to accomplish certain motor tasks. Gross motor improvement is a part of education, especially the experiences of motion on the growth and development of children as a whole [6]. Based on the previous result, especially 5 th grade class students and has been adapted to the character of elementary school students, Dayu Gymnastics also has an effective influence for students in learning physical education. Therefore, at this time overall potential possessed by children needs to be encouraged therefore they develop it optimally.

According to the explanation above, we can identify that students in special growth ages will be curiosity. Through the students of elementary school, the development of movement in children can be stimulated in order to optimal development. The development of motor skills roughly discusses the parts of the body that require a certain collection of muscles. Fine motor development uses fine muscles in the feet and hands. Moreover, imperative movement skills reflect the building of movement particular skills necessary for being active physically joining the games or practicing in sports [7].

Various methods are used to develop gross motor skills therefore children are able to develop their physical motor skill. One of the ways which create children to be active, normal, and happy basically are using gymnastics activities. Gymnastics is a sport which involves the performance of movements that require strength, speed, and harmony with regular physical movements. Gymnastics are commonly 
applied by people for recreation, relaxation or calming the mind, usually, there are those who do it at home, in the gym, and in the gymnasium or at school. Nowadays many children are used to being taught gymnastics, both by parents and by sports instructors at school. From the previous researchers, gymnastic among children had significant improvement in general body coordination and shaped physical self-concept [8]. Further, they found that the intervention of gymnastic was found to be of special advantages for developing among proficiency in children's movement competence and physical self-concept in elementary children. The quality of general movement among children especially external focus on performance resulted superior movement form and greater jump height than did the other two conditions. The present findings described that, similar to other tasks, the performance of form-based skills which can be enhanced relative simply by convenient external focus instructions [9].
Subjects in this study were 25 students from the Islamic Center Elementary School of Samarinda. It consisted of 15 male students and 10 female students. The students were taken from the 4th class to participate in observation and treatment. Based on the results of interviews with teachers and according to observation, students have almost the same level of developmental achievement in every aspect of their development which included as low particularly in rough motor skills. In accordance with this, when researchers conducted observations on the basic movements of aspects of daily gross motor development showed that children are able to create movements such as walking, running, climbing, jumping and kicking. However, when catching and throwing balls children still have difficulty in coordinating the movements especially of their eyes, feet, head, and hands. The direction of the ball that comes to be caught sometimes misses and falls as usual. Meanwhile, the position when they throw a ball is not appropriate yet on the target pitch. The steps below explain each cycle in the middle of the treatment process.

\section{METHOD}

Table 1 Description of Activities of each cycle stage (1. Curriculum analysis, 2. Creating RPP, 3. Arranging Instruments, 4. Prepare learning aid, 5. Arrange evaluation, and 6. Prepare the practice of rhythmic gymnastics)

\begin{tabular}{|ll|}
\hline \multicolumn{1}{|c|}{ Stages } & \multicolumn{1}{c|}{ Cycle I } \\
\hline $\begin{array}{l}\text { Implementation } \\
\text { Observation }\end{array}$ & $\begin{array}{l}\text { Carry out the planned learning scenario, this stage is carried out with the observation phase of the impact of actions. } \\
\text { Observations on the application of physical education direct learning methods approach to play with modification } \\
\text { tools that are applied to the physical education learning process. } \\
\text { Analyze the results of observations and interpretations so that conclusions are obtained that need to be improved } \\
\text { and what needs to be maintained }\end{array}$ \\
\hline \multicolumn{1}{|c|}{ Stages } & $\begin{array}{l}\text { Cycle II } \\
\text { The action is associated with the results achieved in the first cycle as an improvement effort. In addition, student } \\
\text { activity sheets and formative tests were also compiled to collect data on student activities. }\end{array}$ \\
$\begin{array}{l}\text { Implementation } \\
\text { Observation } \\
\text { Reflection }\end{array}$ & $\begin{array}{l}\text { Carry out an improved learning scenario in accordance with the evaluation in the first cycle } \\
\text { The observations made using the observation worksheet see when students follow the learning process. }\end{array}$ \\
\hline
\end{tabular}

Each criterion of indicator would percentages by using KMK (rough motoric skills) pattern formula as follows: $\mathrm{KMK}=$ scored gained by the students/maximum scored $\mathrm{x}$ $100 \%$. After gaining KMK value, the next step would be found the average value of each cycle. The pattern as follows: $\mathrm{x}=$ total value from all of the students/total number of students.

Table 2 Prior observation results

\begin{tabular}{|cccl|}
\hline No. & Indicator & Observation (\%) & \multicolumn{1}{c|}{ Criteria } \\
\hline 1. & Agility & $27 \%$ & Quite agile \\
2. & Balance & $26 \%$ & Quite balanced \\
3. & Flexibility & $25 \%$ & Quite flexible \\
Rough Motor Skills & $26 \%$ & Fair \\
\hline
\end{tabular}

Based on the data above (Table 1), it can be revealed that in the initial conditions before taking the action, (a) in the aspect of flexibility shows $27 \%$ with sufficiently flexible criteria, students indicated had less flexible movements and have not been able to coordinate the movements of their limbs when participating in rhythmic gymnastics activities; (b) aspect balance $26 \%$ with sufficiently balanced criteria, same students could not maintain their body balance but occasionally falls, and had not been able to coordinate the movements of his limbs when following the rhythmic gymnastics activities (c) the agility aspect presented $25 \%$ with less agile criteria it was because several students did not follow the rhythmic gymnastics activities.

\section{RESULTS AND DISCUSSION}

The result and discussion in this study will be explained detail in this portion. The observation result divided into several parts. There was Class Action Research (CAR) process executed as well as treated. The first observation was a result of cycle 1 . As the cycle 1 was not resulted 
maximal target, it was followed by cycle 2 which had similar steps from the previous cycle. Both of the steps had four meeting in each cycle. Moreover, it had three indicators concerned of rhythmic movement namely agility, balance, and flexibility. The assessment was is the rough motor skills. The cycle was regardless the prior observation. In fact, in the second cycle the target was maximal gained. It can be seen based on the comparison accounting.

Table 3 Observation results of cycle I

\begin{tabular}{|clccccc|}
\hline & & \multicolumn{4}{c|}{ Meeting } & \multirow{2}{*}{ Average } \\
\cline { 3 - 6 } No & Indicator & $\begin{array}{c}\text { I } \\
\text { II }\end{array}$ & $\begin{array}{c}\text { III } \\
\mathbf{( \% )}\end{array}$ & $\begin{array}{c}\text { IV } \\
\mathbf{( \% )}\end{array}$ & $\mathbf{( \% )}$ & $(\mathbf{\% )})$ \\
\hline 1 & Agility & 49 & 51 & 51 & 56 & 51.6 \\
2 & Balance & 50 & 52 & 52 & 57 & 52.6 \\
3 & Flexibility & 56 & 55 & 54 & 56 & 56 \\
\multicolumn{6}{c}{ Rough Motor Skills } \\
\hline
\end{tabular}

Based on Table 3 above shows that there has been an increasing in Cycle I since pre-action (pre-action was applied as the comparison to check the students' ability in rough motor skills prior the CAR process). This can be seen in the Cycle I action which described that: (a) in the aspect of flexibility shows $56 \%$ with flexible criteria, the child shows flexible movements in part of his limbs and can coordinate movements when following the rhythmic gymnastics; (b) the aspect balance of $52.6 \%$ with balanced criteria, the child is able to maintain his body balance, but has not been able to coordinate movements when following the rhythmic gymnastics; (c) the agility aspect shows $51,6 \%$ with the criteria of agility, the students shows agile body movements, but had not been able to coordinate movements when following the rhythmic gymnastics. From these results, the rough motor skills through rhythmic gymnastics on average in overall aspects it was showed by the percentages $53.4 \%$ as the highest level.

Table 4 Observation results of cycle 2

\begin{tabular}{|c|c|c|c|c|c|c|}
\hline \multirow[b]{2}{*}{ No } & \multirow[b]{2}{*}{ Indicator } & \multicolumn{4}{|c|}{ Meeting } & \multirow[b]{2}{*}{$\begin{array}{c}\text { Average } \\
(\%)\end{array}$} \\
\hline & & $\begin{array}{c}I \\
(\%)\end{array}$ & $\begin{array}{c}\text { II } \\
(\%)\end{array}$ & $\begin{array}{l}\text { III } \\
(\%)\end{array}$ & $\begin{array}{l}\text { IV } \\
(\%)\end{array}$ & \\
\hline 1 & $\overline{\mathrm{Ag}}$ & 70 & 72 & 83 & 86 & 77.8 \\
\hline 2 & Balance & 72 & 76 & 87 & 89 & 81 \\
\hline 3 & Flexibility & 78 & 82 & 88 & 89 & 84.3 \\
\hline \multicolumn{6}{|c|}{ Rough Motor Skills } & 81 \\
\hline
\end{tabular}

Based on Table 4 above shows that there was an increased level and improvement than Cycle I to Cycle II. This can be depicted that in the action of Cycle II which shows that (a) in the aspect of flexibility of $84,3 \%$ showed the percentage was very flexible as a criteria, the children showed flexible or non-rigid movements and can coordinate the movements of his limbs when participating in rhythmic gymnastics activities; (b) on aspects a balance, it can be revealed that the result was $81 \%$, it means that the criteria included as quite balance, children are able to maintain body balance and were able to coordinate their limbs when participating in rhythmic gymnastics activities; (c) in the agility aspect of $77,8 \%$ depicted that the percentage reached the very agile criteria, the students show agile body movements and can coordinate his limbs when participating in rhythmic gymnastics activities.

Table 5 The comparison results and percentage of rough motor skill between cycle i and cycle II

\begin{tabular}{|cccc|}
\hline No & Indicator & Cycle I (\%) & Cycle II (\%) \\
\hline 1 & Agility & 51.6 & 73 \\
2 & Balance & 52.6 & 76.6 \\
3 & Flexibility & 56 & 78.8 \\
Rough Motor Skills & 53.4 & 76 \\
\hline
\end{tabular}

Based on Table 5, it shows that there was an increase from Cycle I to Cycle II. In the aspect of the flexibility aspect increased by $28,3 \%$ from $56 \%$ with the criteria for flexibility increasing to $84,3 \%$ with very flexible criteria, the balance aspect increased from 52,6\% with the balanced criteria to $81 \%$ with the criteria very balanced which means an increase of $28,4 \%$, in the aspect of agility experienced an increase of $26,5 \%$ from $51,6 \%$ with fairly agile criteria increased to $77,8 \%$ with very agile criteria.

From the observations that have been calculated and interpreted into four levels [10], namely:

a. $(0 \%-25 \%)$ : low

b. $(26 \%-50 \%)$ : moderate

c. $(51 \%-75 \%)$ : high

d. $(76 \%-100 \%)$ : very high

The results of action research from pre-action, Cycle I and Cycle II were $26 \%$ with medium criteria, 53,4\% which interpreted as fine criteria, and $81 \%$ with very high criteria after the action done by the researchers. By its result, it can be concluded that several factors of rough motor skills between children especially in ICES (Islamic Center Elementary School) maybe influenced and depend on the teacher treatment in giving an explanation about the material. furthermore, the more they do the exercise in the same things, it is obviously it will give good results. in other words, due to the fact that they have done the treatment in agility rough motor skills, finally, they have a high balance, agility, and flexibility. This present result was similar to the previous study which shown that the fantasy gymnastic was effective to boost the children's gross motor. It was depicted by $54.2 \%$ significance. The fantasy gymnastic learning model gave a significant influence on the gross motor students' skills as well as make the students the learning process more active and imaginative [11]. Therefore, the approach (CAR) has become one of the most useful methods for the teacher to develop their students' motoric skills. Further researchers would be recommended to develop the approach in order to reach the appropriate rough motoric skills among children under 12 years old.

\section{CONCLUSION}

According to previous discussion and result, it can be revealed that development of rough motor skill among children especially children which in elementary school age are essential. In this study, CAR (Classroom Action Research) were succeed increase their progress of rough motor skill. It was proved from the two-cycle given for them. In the first cycle the increasing were not showed 
significantly. Even, from the first survey time being observed, the class chosen which was treated tended to be apathetic for the rough motor skill. Finally, in the second cycle treatment they showed the significant improvisation and in rough motor skills especially in their agility, balance, and flexibility. Another benefit from the treatment were student at least felt familiar with traditional music which following the movement. It was intentionally made in order to realize them in local music than modern music which everyday faced by. This study has several recommendations either for practitioner or future researchers. For the practitioner, this study is able to become a reference for them to teach rough motor skills development among children. They have to be able to create the content or movement which make student to be interested to follow. The teacher should be creative to select the movement in order to improve their agility, balance as well as their flexibility. This study is really useful for the future researchers especially to whom that having concern in rough motor skill development among children. This research can be developed for the broader scope not only for CAR study but it can be focused on their commitment, motivation or other variables related to.

\section{REFERENCES}

[1] Sumantri. Model Pengembangan Keterampilan Motorik Anak Usia Dini. Jakarta: Depdiknas. 2005

[2] Mubin, F., Soegiyanto, S., \& Sulaiman, S. Stick Gymnastic Development for Learning Material Rhythmic Activities at Physical Education in Elementary Schools. Journal of Physical Education and Sports, 8(1), 69-75. 2019

[3] Hostetter, A., \& Mainela-Arnold, E. Gestures occur with spatial and motoric knowledge: it's more than just coincidence. Perspectives on Language Learning and Education, 22(2), 42-49. 2015
[4] David, L. G., \& John, C. O. Understanding Motor Development. America. The McGraw-Hill Companies. 2002

[5] Soegiyanto, Soekardi, \& Sukardi. Senam Dayu dalam Pembelajaran Aktivitas Ritmik Pada Siswa Elementary School. Journal of Physical Education and Sports, 4(1), 44-50. 2015

[6] Veldman, S. L., Okely, A. D., \& Jones, R. A. Promoting gross motor skills in toddlers: the active beginnings pilot cluster randomized trial. Perceptual and motor skills, 121(3), 857-872. 2015

[7] Barnett, L. M., Stodden, D., Cohen, K. E., Smith, J. J., Lubans, D. R., Lenoir, M., ... \& Lander, N. J. Fundamental movement skills: An important focus. Journal of Teaching in Physical Education, 35(3), 219225. 2016

[8] Rudd, J. R., Barnett, L. M., Farrow, D., Berry, J., Borkoles, E., \& Polman, R. The Impact of Gymnastics on Children's Physical Self-Concept and Movement Skill Development in Primary Schools. Measurement in Physical Education and Exercise Science, 21(2), 92100. 2017

[9] Abdollahipour, R., Wulf, G., Psotta, R., \& Palomo Nieto, M. Performance of gymnastics skill benefits from an external focus of attention. Journal of Sports Sciences, 33(17), 1807-1813. 2015

[10] Acep Yoni, dkk. Menyusun Penelitian Tindakan Kelas. Yogyakarta: Familia. 2005

[11] Eriani, E., \& Dimyati, D. Fantasy Gymnastic as an Active and Imaginative Learning Model to Children's Gross Motor. In International Conference on Special and Inclusive Education (ICSIE 2018). Atlantis Press. 2019. 